\title{
ANALYTICAL REPORT ON WATER QUALITY OF RESIDENTIAL AND INDUSTRIAL AREA OF EAST JAKARTA, JAKARTA, INDONESIA
}

Wiwit Suprihatiningsih ${ }^{1}$, Titia Izzati ${ }^{2, *}$, Anggasta Rafka Adam Pratama ${ }^{2}$, Bagas Enggar Pambudi ${ }^{2}$, Dede Zulfikar ${ }^{2}$, and Yusuf Eko Utomo

\author{
${ }^{1}$ Mechanical Engineering Program, Engineering Faculty, Universitas Mercu Buana, 11650, Jakarta, Indonesia \\ ${ }^{2}$ Industrial Engineering Program, Engineering Faculty, Universitas Mercu Buana, 11650, Jakarta, Indonesia \\ E-mail: wiwit.suprihtiningsih@mercubuana.ac.id, titia.izzati@mercubuana.ac.id, *tizzati@gmail.com, anggastarafka@gmail.com, \\ bagasenggarprambudi@gmail.com, yusufeko1@gmail.com
}

\begin{abstract}
The purpose of this research is to analyze the quality of water in residential areas and industries, East Jakarta. Research was conducted to analyze the quality of $\mathrm{pH}, \mathrm{Ec}, \mathrm{TDS}$, the temperature using a multimeter (waterproof tester). The results of this research are as follows: 1 . The value of $\mathrm{pH}(8.0-8.9), E C(340 \mu \mathrm{S}-144 \mu \mathrm{S})$, the value of $T D S(171 \mathrm{ppm}-438 \mathrm{ppm})$, the value of temperature $\left(30.10^{\circ} \mathrm{C}-31.54^{\circ} \mathrm{C}\right) .2$. Industrial activity and population affect water quality. The water in the area of East Jakarta still safe used/consumed.
\end{abstract}

Keyword: East Jakarta, industry, residential, washing, water quality.

\section{INTRODUCTION}

The benefits of water for the community have a very important role in improving the health of the environment or the community, i.e. have a role in lowering the number of sufferers of the disease, especially those related to water, and play a role in raising the standard or level/quality of life of the community. There are several important factors that determine the quality of the water in all regions in Indonesia this, factors such as acidity $(\mathrm{pH})$, electrical conductivity (EC), total dissolved solid (TDS), and temperature of water [1-5]. Many pollution data have been reported in some journals, especially in the area surrounding the capital city, Jakarta[6-15]. In addition, the social welfare and the limitation of open space have been studied in Cibubur, close to Jakarta, with the support of the Ministry of Young and Sport Of Republic Indonesia[1618].

Activities conducted in neighbourhoods or industrial can affect the value of the four physical factors, such temperature, acidity, electrical conductivity, and solid dissolved in the water. Research was conducted to analyze the water quality in a residential area and industrial area located in East Jakarta. This area is a densely populated area to provide shelter and also many factories and offices. The purpose of this research was to look out and analyze the quality of tap water, the water washing, and water existing office space in the area of East Jakarta. By conducting measurements against $\mathrm{pH}, \mathrm{EC}$, TDS, and temperature, the quality of water in the area of East Jakarta can be check easily. This research also can see the difference in the quality of water in residential areas, industrial areas, and water the rinsing in East Jakarta.

\section{RESEARCH METHODS}

The multimeter is used to perform analysis of $\mathrm{pH}, \mathrm{EC}$, TDS, and temperature on water quality $[19,20]$ in the area of East Jakarta. The materials used in the process of analyzing the quality of the water is tap water that comes from the wash water, the residential that are derived from localities, as well as tap water that comes from the

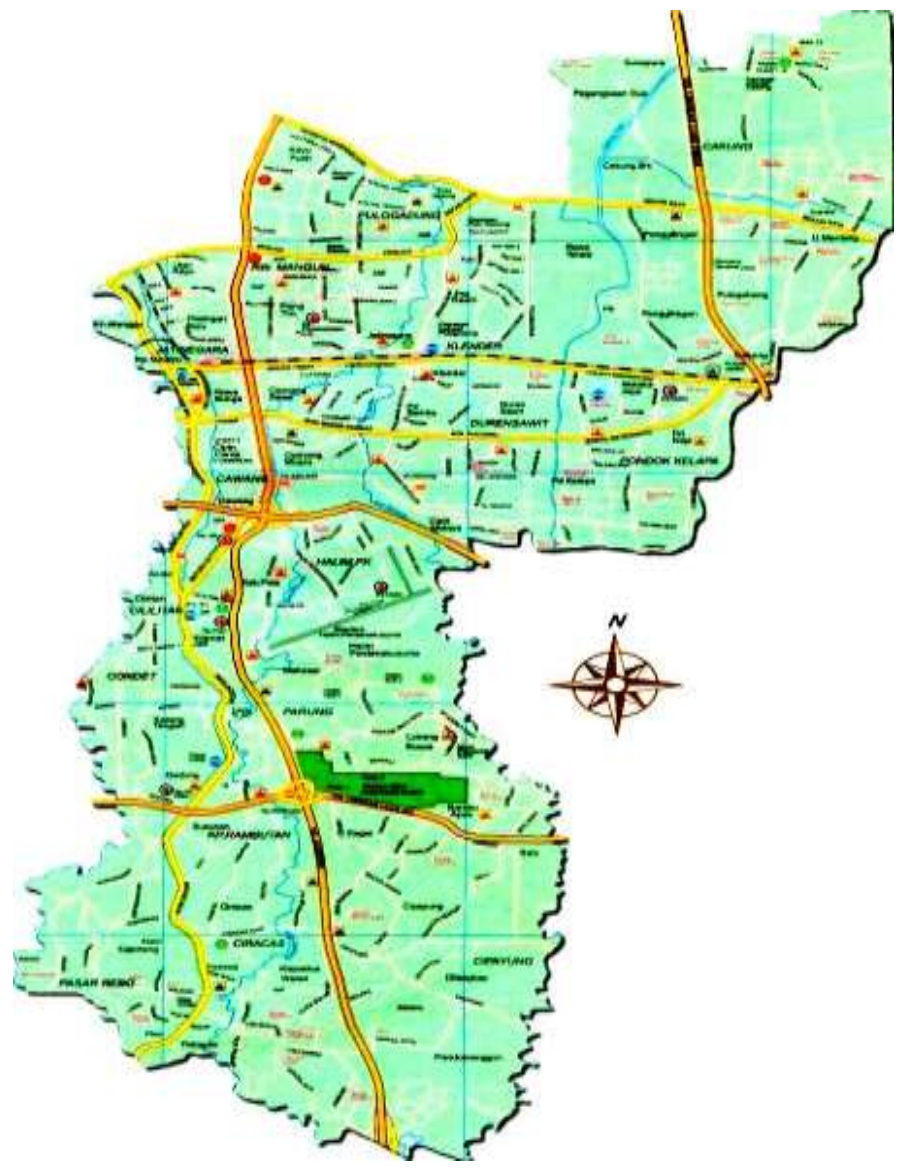

Figure 1. East Jakarta map

office/industrial area.

This research was conducted for 8 weeks. It has 20 points, chosen randomly, and it starts from September 1, 2017 until October 31, 2017 in the area of East Jakarta. 


\section{RESULTS and DISCUSSION pH}

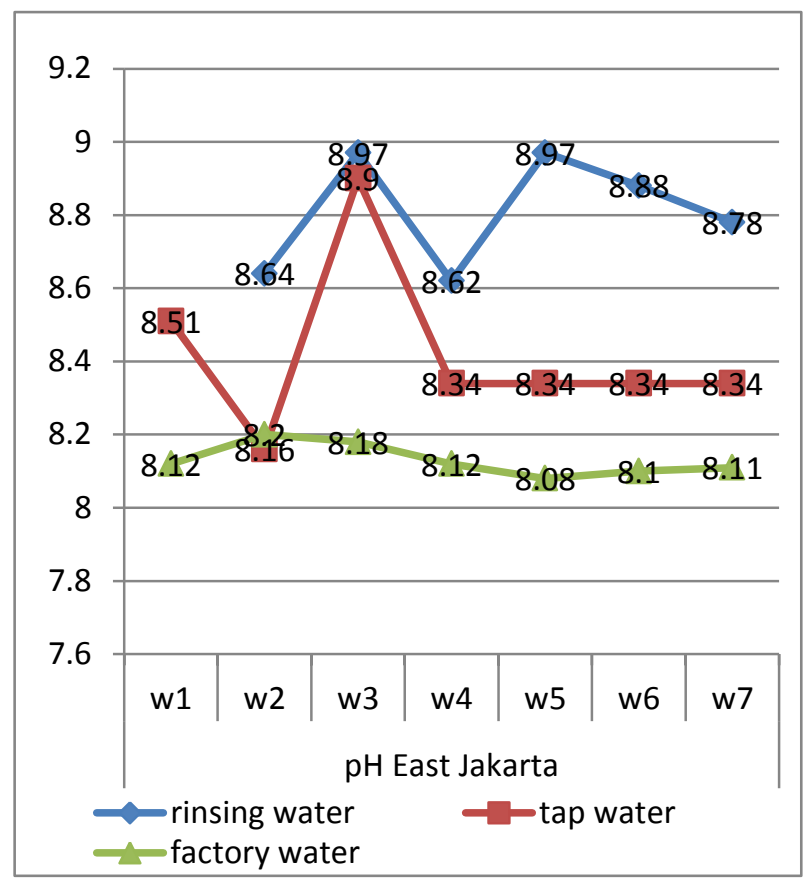

Figure 2. pH Graphs

The results of $\mathrm{pH}$ for tap water in the residential area of East Jakarta shows the average value of 8.11. The $\mathrm{pH}$ has increased in week 1 to week 2 , in week 2 to week 5 the pH decreased, in week 5 to week 7 has increased in week 7 , $\mathrm{pH}$ values decreased until week 8 .

The results of $\mathrm{pH}$ for tap water in the area of East Jakarta Office indicates the average rating 8.8. The $\mathrm{pH}$ value in week 1 has decreased to the 2 nd in week 2 , the $\mathrm{pH}$ has increased to week 3 , in week $3 \mathrm{pH}$ decline again until

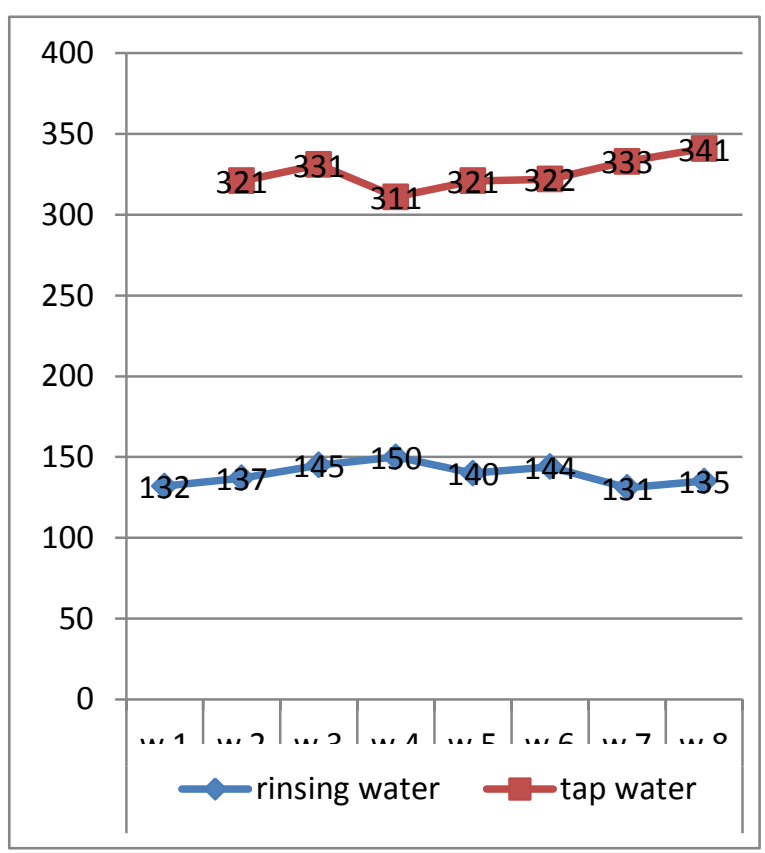

Figure 3. EC Graphs (in $\mu S$ ) week 4 , on Sunday to experience increased $\mathrm{pH} 4$ to 5 in week 5 , pH down again until week 7 , in week $7 \mathrm{pH}$ increased until week 8 .

The results of the water $\mathrm{pH}$ to the rinsing in a residential area of East Jakarta shows the average value of 8.95. week 2 to week $5 \mathrm{pH}$ values stable, then in week $5 \mathrm{pH}$ decline until week 7 , in week $7 \mathrm{pH}$ has increased up to week 8 .

EC

The result of the measurement of tap water for the value of $\mathrm{EC}$ in the residential of East Jakarta has an average rating of 330. In week 2 of EC experience increased until week 3, in week 3 of EC decreased until week 4 , on Sunday to 4 EC experienced improvement until week 8. The highest obtainable EC value in week 8 with a value of 344 while the lowest EC values obtained in week 4 with a value of 314.

The result of the measurement of the water-washing for the value of EC in the residential of East Jakarta has an average rating of 144 .

In week 1 of EC experience increased until week 4, on Sunday to 4 EC experienced a decline until week 5, in week 5 of EC experience increased until week 6 , in week 6 EC experienced a decline until week 7, in week 7 of EC experience an increase in the up to week 8 . The highest obtainable EC value in week 4 with a value of 152 EC value while lowest were obtained in week 7 with the value of 131 .

\section{TDS}

The result of the measurement of tap water for TDS in the residential of East Jakarta has an average value of 400. In week 1 TDS has increased up to 2 weeks, in week 2 TDS decline until week 3 , in week 3 TDS value is stable until week 4 , in week 4 TDS has increased until week 5, in week 5 TDS value is stable until week 8 . The value of the highest obtainable TDS in week 2 while the lowest TDS value obtained in week 3 .

The result of the measurement of the water'S TDS value for Office in East Jakarta Office has an average value of 220. In week 1 TDS has increased up to 2 weeks, in week 2 TDS decline until week 3 , in week 3 TDS has increased up to 4 weeks, in week 4 TDS decline until week 5 , in week 5 TDS. The graph of TDS increase until week 6 , in week 6 TDS decline until week 7, in week 7 TDS has increased until week 8 . The highest value obtained in week 8 while the lowest value in a can in week 5 .

The result of the measurement of the waterwashing/rinsing for TDS in East Jakarta had the average value of 177. In week 2 TDS decline until week 4, in week 4 TDS value is stable until week 5, in week 5 the value of TDS has increased up to week 7, in week 7 TDS value decline until week 8 . The value of the highest obtained TDS in week 7 while the lowest TDS value obtained in week 8 . 


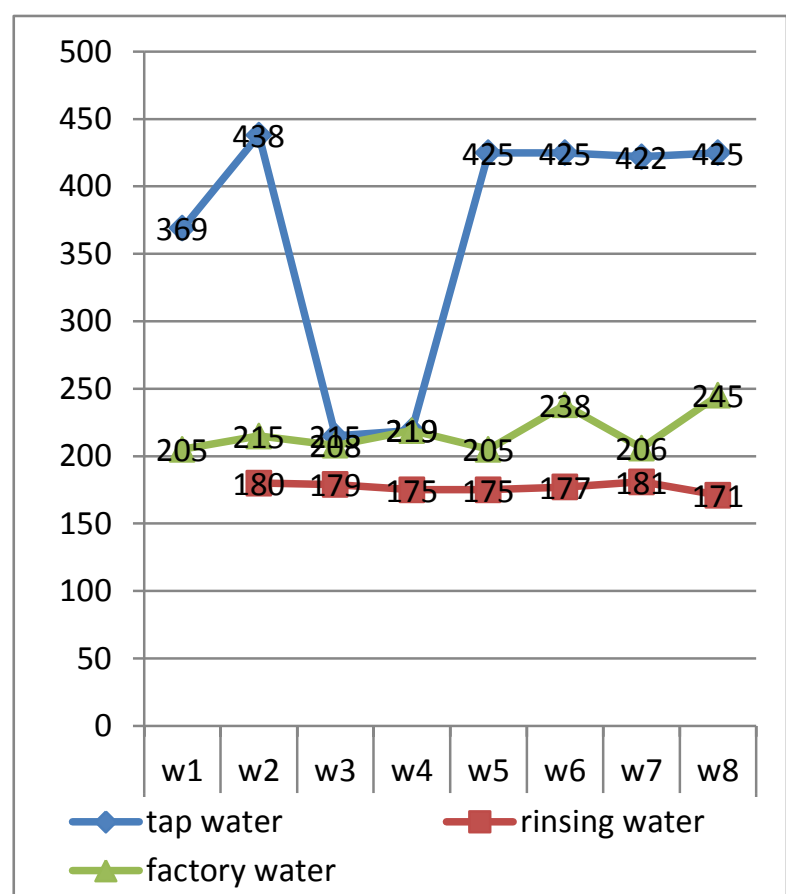

Figure 4. TDS Graphs (in ppm)

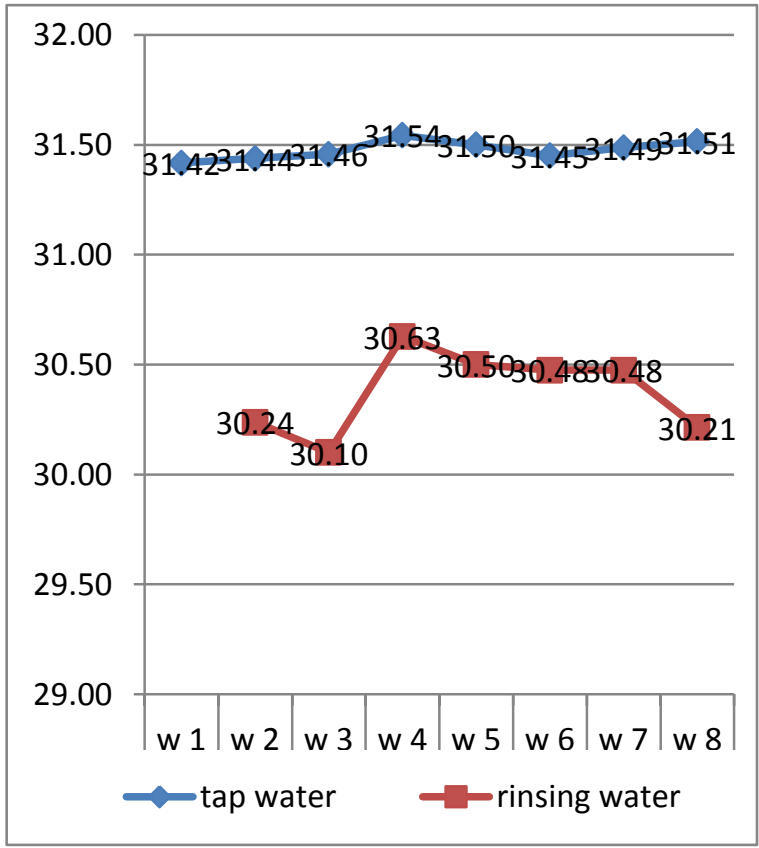

Figure 5. Temperature Graphs $\left(\right.$ in $\left.^{\circ} \mathrm{C}\right)$

\section{TEMPERATURE}

The results of the measurement of the temperature of the tap water in the area of East Jakarta had an average rating of $31.45^{\circ} \mathrm{C}$. In week 1 temperature increase until week 4 , on Sunday to 4 temperature decline until week 6 , in week 6 temperature has increased until week 8 .

The results of measurements of water temperature washing/rinsing area in East Jakarta had an average rating of $30.25^{\circ} \mathrm{c}$. in week 1 of temperature decline until week 2 , in week 2 to week experience increased temperature to 3 , in week 3 temperature experience the decline in the 7 th to Sunday.

\section{Description of research results}

The data on this research indicates the wash water $\mathrm{pH}$ greater than $\mathrm{pH}$ of tap water and water Office, high $\mathrm{pH}$ water washing detergent usage caused by resulting in the nature of a rinsing water becomes more alkaline. Meanwhile, the value of most small office water $\mathrm{pH}$ due to water in the offices/industrial has been mixed by materials that result in "chemical properties of the water becomes more acidic and the $\mathrm{pH}$ becomes smaller.

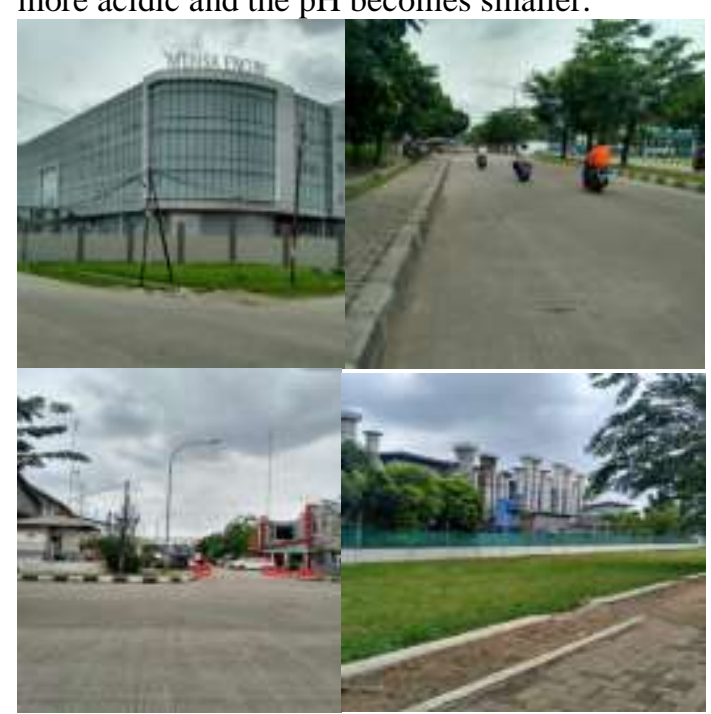

Figure 6. Offices and industrial areas

According to government regulations, PERMENKES (regulation of the Minister of health) No. 416 of 1990 [21], drinking water maximum and minimum limits of the $\mathrm{pH}$ range of 6.5-8.5 are used [22]. means that tap water in the area of East Jakarta was still safe to use due to the $\mathrm{pH}$ of the water of the eastern coastline of Jakarta has the average value of 8.11-8.35. The EC minimum tap water is $0.5-0.8$ $\mathrm{mS} / \mathrm{cm}(1 \mathrm{mS} / \mathrm{cm}=500 \mathrm{ppm}=500 \mathrm{mg} / \mathrm{l})$ so that it can be summed up tap water in East Jakarta has a dense concentration of a chemical solution that is good enough. Based on the results of the research, the results obtained under the TDS limit for consumption with TDS> $500 \mathrm{mg} / \mathrm{l}$ (492 PERMENKES 19 April 2010 concerning drinking water quality requirements) [13], so it is concluded that the groundwater in the area of East Jakarta is quite good to be consumed.

\section{CONCLUSION}

1. The $\mathrm{pH}$ of the water in the area of East Jakarta 8.0-8.9 (alkaline water), EC (340 $\mu \mathrm{S}-144 \mu \mathrm{S})$, the value of TDS (171 ppm-438 ppm), the value of temperature $\left(30.10^{\circ} \mathrm{C}-31.54{ }^{\circ} \mathrm{C}\right)$. .

2. Factors affecting the change in the value/quality of water is overcrowding, sewage, and the lack of green fields.

3. Water in East Jakarta is still eligible for daily life.

\section{ACKNOWLEDGEMENTS}

This research was supported by The Students of Chemistry and Environmental Study Classes Reg 1 \& 2: $16066 / \mathrm{Gasal} / 2017-2018$ and The Students of Environmental Engineering Study Class Reg 2: 82011/Gasal/2017-2018, Universitas Mercu Buana Kampus D, Indonesia.

\section{REFERENCE}

1. Izzati, T., 2016. An Initial Study Of The Air Pollution Through Rainwater In An Industrial Area Of 
Cikarang, West Java, Indonesia (A Case Study). analysis, 11: p. 12.

2. Stauffer, J., 2013, The water crisis: Constructing solutions to freshwater pollution. 2013: Routledge.

3. Stern, A.C., 2014, Fundamentals of air pollution. 2014: Elsevier.

4. Caviglia-Harris, J.L. and R.T. Melstrom, 2015. Airing Your Dirty Laundry: A Quick Marketable Pollution Permits Game for the Classroom. The Journal of Economic Education, 46(4): p. 412-419.

5. Hocking, M.B., 2016, Handbook of chemical technology and pollution control. 2016: Elsevier.

6. Izzati, T., 2016. An Initial Study Of The Air Pollution Through Rainwater In An Industrial Area Of Bekasi. World Chemical Engineering Journal, 1(2).

7. Izzati, T., 2016. An Initial Study Of The Air Pollution Through Rainwater In An Industrial Area Of Cikarang, West Java, Indonesia (A Case Study). Science International, 28(4).

8. Izzati, T., 2017. Water Quality Analysis Of Residential And Industrial Areas In Bogor, West Java, Indonesia. Science International, 29(2): p. 37-370.

9. Izzati, T., et al., 2016. An Initial Study Of Laundry Industrial Effects To The Water Pollution In East Jakarta. IOSR Journal of Environmental Science, Toxicology and Food Technology 10(9): p. 35-37.

10. Izzati, T., et al., 2016. An Initial Study Of Industrial Area's Effects For The Air Pollution Through Rainwater In East Jakarta. IOSR Journal of Mechanical and Civil Engineering, 13(4): p. 159-162.

11. Izzati, T., et al., 2016. An Initial Study Of Laundry Industrial Effects To The Water Pollution In Bekasi. IOSR Journal of Business and Management, 18(8): p. 109-111.

12. Amalia, M., B.P. Resosudarmo, and J. Bennett, Editors. 2013, The Consequences of Urban Air Pollution for Child Health: What does Self Reporting Data in the Jakarta Metropolitan Area Reveal?,

13. Baum, G., et al., 2015. Local and regional impacts of pollution on coral reefs along the Thousand Islands north of the megacity Jakarta, Indonesia. PloS one, 10(9): p. e0138271.

14. Resosudarmo, B.P. and L. Napitupulu, 2004. Health and economic impact of air pollution in Jakarta. Economic Record, 80(s1): p. S65-S75.
15. Izzati, T., 2017. An Initial Study of the Water Pollution Analysis at Residential, Office Building and Industrial Area's in Bogor. World Chemical Engineering Journal, 1(4): p. 31-34.

16. Izzati, T., et al., 2015. Social Welfare Programs For Young Society In Indonesia. Science International, 27(5): p. 4715-4717.

17. Izzati, T., et al., 2015. An Education Profile Of Indonesian Youth In 2009-2013. Science International, 27(2): p. 1457-1460.

18. Izzati, T. and Y. Poerwanti, 2014. Enhancing The Productivity And Multifunctionality Of Open Space Using Simple Techniques In Green Buildings. Science International, 26(2): p. 689-690.

19. Izzati, T., 2017, Kimia dan Praktikumku. Buku Panduan Praktikum Kimia Sederhana Bagi Mahasiswa Teknik Mesin. 2017, Jakarta: Pustaka Mandiri.

20. Izzati, T., 2017, Kimia dan Praktikumku. Buku Panduan Praktikum Kimia Sederhana Bagi Mahasiswa Teknik Industri. 2017, Jakarta: Pustaka Mandiri.

21. Siahaan, N.H.T., 2004, Hukum Lingkungan dan Ekologi Pembangunan. 2004: Erlangga.

22. Astuti, L.T.M., et al., 2015. Model of sustainable wellbeing on decent house Study case of Bekasi City, West Java, Indonesia. Procedia Environmental Sciences, 28: p. 370-379. 